\title{
DESAPROPRIAÇÃO PARA FINS DE REFORMA URBANA
}

\author{
EDILSON PEREIRA NOBRE JÚNIOR*
}

1. A propriedade urbana e sua função social; 2 . Objeto e competência; 3. Pressupostos; 4. Indenização; 5. Destinação do bem expropriado; 6. Palavras finais.

\section{A propriedade urbana e sua função social}

Desde princípios da centúria passada, a noção de propriedade foi alvo, sob o prisma jurídico, de notável transformação. Da concepção sacré et inviolable, plasmada pelo art. 17 da Declaração dos Direitos do Homem e do Cidadão de 1789, legado da Revolução Francesa, com os adornos inscritos no art. 544 do posterior Código Civil de $1804^{1}$, capitulou ante a necessidade de ser harmonizada com os imperativos da sociedade.

O abandono da exploração da coisa, ou a sua destruição, outrora faculdade do titular do domínio, passou a ser reputada como ilícito, haja vista a carência de bens pela grande maioria das pessoas, destinatários finais da ordem jurídica, para a satisfação de suas necessidades básicas de produção, moradia e consumo.

A tônica das novidades vem assimilada pelo enunciado da parte final do art. 153, da Constituição de Weimar, ao proclamar: "A propriedade obriga e seu uso e exercício devem ao mesmo tempo representar uma função social". Esta mensagem, que semeara o constitucionalismo do segundo pós-guerra (art. 42, Constituição italiana de 1948; art. $33^{\circ} .1$ da Constituição da Espanha; o art. 14.2 da Constituição alemã de 1949; o Preâmbulo da Constituição francesa de 1946, possuidor de valor

* Juiz Federal lotado na Seção Judiciária do Rio Grande do Norte. Professor da Universidade Federal do Rio Grande do Norte e da Especialização em Direito Administrativo da Faculdade de Direito do Recife - UFPE. Mestre e Doutorando pela Faculdade de Direito do Recife - UFPE.

I Eis o teor do preceptivo, obtido em tradução livre: "A propriedade é o direito de gozar e dispor das coisas da maneira a mais absoluta, desde que não se faça um uso proibido pelas leis ou regulamentos". 
constitucional por Remissão do Preâmbulo da Lei Fundamental de 04 de outubro de 1958), teve o seu conteúdo bem sumariado por Gustav Radbruch, ao acentuar que "a propriedade privada aparece já hoje como um campo de ação livre, confiado pela colectividade à iniciativa privada do indivíduo, mas confiado somente na expectativa de que este faça dela um uso social, sob pena dela lhe ser retirada, se esta expectativa se não verificar. Por outras palavras: a propriedade passou a ser considerada um direito limitado e condicionado, e deixou de ser um direito sem condições e limites, 'sagrado e inviolável', que se justifica por si mesmo"'.

O direito constitucional pátrio não ficou fora dessa sintonia, emprestando acerto ao dito do mestre Caio Tácito: "Ingressa, por essa forma, no direito público, a noção de que à propriedade corresponde uma função social: ao poder do proprietário se acresce o dever perante a comunidade na qual ele se integra" ${ }^{3}$.

Daí que a Constituição de 1934 consignara, além da garantia do direito de propriedade, que o seu uso não poderia ser exercido em contraposição ao interesse social ou coletivo, na forma determinada em lei (art. 113, § 17, primeira parte). Por sua vez, o documento resultante da assembléia constituinte de 1946, no seu art. 147, outorgara ao legislador competência para que os entes políticos pudessem desapropriar por interesse social, promovendo, assim, o justo reparto da propriedade, sendo, para tanto, editada a Lei 4.132, de 10-09-62. Posteriormente, a Emenda Constitucional 10, de 09-11-64, foi mais além, instituindo, entre nós, a possibilidade de desapropriação por interesse social como forma de sancionar o proprietário remisso em adequar a utilização de imóveis rurais à sua função social, procedendo-se ao pagamento da indenização mediante o pagamento em títulos especiais da dívida pública, a qual, com algumas variantes, foi mantida pela Constituição de 1967 (art. $157, \S \S 1^{\circ}$ a $6^{\circ}$ ) e pela Emenda Constituição $01 / 69$ (art. $161, \S \S 1^{\circ}$ a $\left.5^{\circ}\right)^{4}$.

2 Filosofía do Direito. Tradução e prefácios do Professor L. Cabral de Moncada. 6. ed. Coimbra: Armênio Amado Editor, 1979. p. 280.

3 O direito de propriedade e o desenvolvimento urbano. In: Temas de Direito Público (Estudos e Pareceres). Rio de Janeiro: Renovar, 1997. v. 1, p. 582.

4 No solo patrial, os autores costumam, pelo didático hábito de classificar, bipartir a desapropriação por interesse social. Carlos Mário da Silva Velloso (Desapropriação para fins de reforma agrária - apontamentos. Revista de Direito Público, São Paulo, n. 34, p. 13, abr./jun. 1975) aludira à existência de uma espécie genérica, fundada no art. $153, \S 22$, e, ao seu lado, outra, de cunho específico, lastreada pelo art. 161, ambos da Constituiçāo pretérita. Adilson de Abreu Dallari (Desapropriação: conceitos e preconceitos. In: MELLO. Celso Antônio Bandeira de (Coord.). Curso de Direito Administrativo. São Paulo: Revista dos Tribunais, 1986. p. 34) se reportava, na ordem constitucional anterior, às denominações "desapropriações ordinária e extraordinária". Após 0510-88, José Afonso da Silva (O Município na Constituição de 1988. São Paulo: RT,1989. p. 63) diz que a propriedade urbana pode ser expropriada de duas maneiras, qual seja a desapropriação comum, a que se refere o art. $5^{\circ}, \mathrm{XXIV}$, da CF, mediante prévia e justa indenização em dinheiro, e a desapropriação-sanção, voltada a reprimir o não cumprimento de obrigação imposta ao proprietário, regida pelo art. 182, $\$ 4^{\circ}$, do mesmo diploma. Reportando-se à desapropriação como sanção, Clóvis Beznos (Desapropriação. In: MELLO, Celso Antônio Bandeira de (Coord.). Direito Administrativo na Constituição de 1988. São Paulo: RT, 1991. pp. 112-113 e 115.) declara que, uma vez fixado no ordenamento o dever de atribuir uma função à propriedade, exsurge que o seu 
Esse, em síntese, o quadro existente antes da promulgação da Lei Fundamental de 05-10-88, estando a desapropriação-sanção restrita aos imóveis rurais.

As radicais mudanças experimentadas pela sociedade moderna, com a substituição da fonte de produção campesina pela industrial, forjaram, como cenário complementar, o elevado aumento populacional das cidades, ocasionando o grave problema da falta de moradia, erigida à estatura de direito social com a alteração imprimida ao art. $6^{\circ}$, caput, da CF/88, pela EC 26/00.

A seriedade da questão do déficit habitacional em nosso país é demonstrada pelo alto grau de densidade populacional nas cidades, revelado, com clareza, pelos dados colhidos pelo IBGE no Censo Democrático 2000, ao aportar na constatação de que a população urbana chegara ao patamar de $81,25 \%$, remanescendo no campo apenas $18,75 \%$ dos habitantes de nosso vasto território.

Por essa razão, providencial a ação do Constituinte de 1988, ao pioneiramente traçar, no texto constitucional, os contornos da função social da propriedade, fazendo não somente para fins rurais, mas igualmente para urbanos.

No que concerne à propriedade urbana, o art. $182, \S 2^{\circ}$, da Lei Básica, dispõe que aquela tem por cumprida a sua função social quando atende às exigências fundamentais de ordenação da cidade, expressas no plano diretor. Este, conforme frisado no art. 182, caput, do mesmo diploma, haverá de respeitar as diretrizes gerais da política de desenvolvimento urbano, fixadas em lei, de estatura ordinária e não necessariamente complementar, cuja competência legislativa é da União ${ }^{5}$, cuja edição teve lugar com a promulgação da Lei 10.257, de 10-07-01, batizada sob a denominação de Estatuto da Cidade.

Integrando o mandamento constitucional, a Lei 10.257/01 detalha, em seu art. 39, caput, o conceito de função social da propriedade urbana, dispondo que as exigências fundamentais de ordenação da cidade, constantes do plano diretor, devem voltar-se a assegurar $o$ atendimento das necessidades dos cidadãos quanto à qualidade de vida, à justiça social e ao desenvolvimento das atividades econômicas, observadas as diretrizes inscritas em seu art. $2^{\circ}$.

descumprimento configura ilícito, lição a que se submete a desapropriação para reforma urbana, na condição de verdadeira penalidade. Noutras plagas, o termo desapropriação-sanção já fora utilizado por Garrido Falla (Tratado de Derecho Aministrativo. 3. ed. Madri: Instituto de Estudos Políticos, 1966. v. II (Parte Geral - Conclusão), p. 255, nota de rodapé B), ao fazer referência à expropriação pelo não cumprimento da função social, disciplinada pelos arts. 71 a 75 da espanhola Ley de 16 de dezembro de 1954, ainda vigente. Para o autor, o caráter sancionador não se reflete na minoração do justo preço, mas na circunstância de o proprietário haver postergado norma legal que the conferia a oportunidade de utilizar um bem, ou uma classe de bens, no sentido de uma determinada função social.

5 Além disso resultar implícito do teor do art. 182, caput, da CF, ao aludir a diretrizes gerais, a dar idéia de modelo uniforme, o que, em um estado federal, é tarefa do ente central, o art. 24, I, da CF, afirma competir à União, aos Estados e ao Distrito Federal, legislar concorrentemente sobre direito urbanístico, incumbindo-se à União gizar as normas de caráter geral. Por esse motivo, a Lei 10.257/01 se impõe à observância obrigatória dos Estados, Distrito Federal e Municípios. 
Mas não é só. Embora tenha o art. 182 da Lei Máxima sido omisso, contrariamente ao que sucedera com o seu art. 186, II, relativo à missão social da propriedade rural, não se pode perder de vista que, no plano urbanístico, tal não é integralizado sem a observância da preservação ambiental, imposta pelo art. 225 daquele diploma ${ }^{6}$.

Nesse sentido, a Lei 10.257/01 trouxe à baila inúmeros dispositivos dessa ordem, entre os quais o que inclui o estudo de impacto ambiental - EIA (art. $4^{\circ}, \mathrm{VI}$ ), sem contar que, entre as diretivas gerais, destinadas a ordenar o pleno desenvolvimento das funções sociais da cidade e da propriedade urbana, constam várias de ordem ambiental, tais como: a) a consideração de que o direito a cidades sustentáveis passa pelo direito ao saneamento ambiental; b) a ordenação e o controle do uso do solo como forma de evitar a deterioração das áreas urbanizadas, a poluição e a degradação ambiental; c) a adoção de padrões de expansão urbana compatíveis com os limites de sustentabilidade ambiental; d) proteção, preservação e recuperação do meio ambiente natural; e) audiência do Poder Público municipal e da população interessada nos processos de implantação de empreendimentos ou atividades com efeitos potencialmente negativos sobre o meio ambiente natural ${ }^{7}$.

Ao não cumprimento da função social pelo proprietário urbano, a Constituição vigente reservou, no seu art. $183, \S 4^{\circ}$, III, a sujeição à desapropriação cujo pagamento é feito mediante títulos da dívida pública ${ }^{8}$. Sobre a análise deste novo instituto recai o presente trabalho, a ser desenvolvido nas céleres linhas abaixo.

Antes do delineamento mais detalhado do tema, mister não confundir a desapropriação para reforma urbana, hipótese de interesse social, com aquela vocacionada à execução de planos de urbanização ou reurbanização, definida como integrante do rol das causas de utilidade pública (art. $5^{\circ}$, alínea $i$, DL 3.365/41), cujo espeque constitucional reside no art. $5^{\circ}$, XXIV, da Lei Maior.

6 O liame entre função social da propriedade e meio ambiente foi bem explanado por Antônio Herman V. Benjamin (Desapropriação, reserva florestal legal e áreas de preservação permanente. Revista do CEJ, Brasília, v.1, n. 3 p. 33-41. set./dez. 1997).

7 Cf. art. $2^{\circ}$, I, VI, alínea $f$ e $g$, VIII, XII e XIII, da Lei $10.257 / 01$. Ver também: a) o art. $4^{\circ}$, III, alínea $c$, que prevê o zoneamento ambiental como instrumento da política urbana; b) o art. $32, \S$ $2^{\circ}$, I, ao tratar do estudo de impacto ambiental nas operações urbanas consorciadas; c) o art. 41, ao tornar obrigatório o plano diretor para as cidades compreendidas na área de influência de empreendimentos, ou atividades com significativo impacto ambiental de âmbito regional ou nacional.

8 Pervagando-se o sistema jurídico lusitano, constata-se figura semelhante quanto à desapropriação para fins de composição urbana, prevista no art. $48^{\circ}$ do Decreto-lei $n^{\circ} 794$, de 05 de novembro de 1976, dirigida aos terrenos próprios para construção, adjacentes às vias públicas de aglomerados urbanos, quando os proprietários, uma vez notificados para aproveitarem-nos em edificaçōes, venham, sem motivo legítimo, a quedarem-se inertes pelo prazo de dezoito meses. A indenização, solvida em moeda corrente, salvo acordo, é calculada tomando-se como base a data em que o proprietário fora notificado para aproveitar o bem. 


\section{Objeto e competência}

A medida em exame incide sobre objeto restrito, consistente no solo, porção da superfície terrestre onde se anda ou se constrói. Não é, todavia, todo e qualquer tipo de solo, mas apenas o urbano, excluindo-se o rural, conforme definição constante do art. $4^{\circ}$, I, da Lei $8.629 / 93$.

Faz-se preciso que se trate de imóvel inserido em área delimitada no plano diretor do respectivo Município. Alfim, terá que referir-se a solo urbano que não esteja edificado, ou esteja subutilizado, ou não utilizado. Em suma, há que se cuidar de imóvel não adequadamente aproveitado.

Tendo em vista a não existência de maiores dificuldades de, no plano vernacular, definir-se o que se deva compreender por solo não edificado, ou não utilizado, o legislador houve por conceituar o imóvel subutilizado como sendo aquele cujo aproveitamento seja inferior ao mínimo definido no plano diretor, ou em legislação deste decorrente (art. $5^{\circ}, \S 1^{\circ}$, Lei 10.257/01).

A competência para a expropriação em foco, como se pode ver do art. $182, \S$ $4^{\circ}$, da Norma Ápice, é privativa dos Municípios e do Distrito Federal, este último por força do art. $32, \S 1^{\circ}$, do mesmo diploma, ao lhe atribuir os afazeres legislativos reservados aos primeiros e aos Estados.

Isso, vale advertir, não impede que a União e os Estados desapropriem imóveis urbanos por interesse social. Mas tal haverá de proceder-se com base no art. $5^{\circ}$, XXIV, da Lei Fundamental, com o pagamento de prévia e justa indenização em dinheiro, aplicando-se, com as devidas adaptações, predominante entendimento doutrinário $^{9}$ e pretoriano ${ }^{10}$ relativo à desapropriação de imóveis rurais por interesse social. Nessa hipótese, a desapropriação haverá de fundar-se nas situações descritas pelo art. $2^{\circ}$, I, IV a VIII, da Lei 4.132/62.

Apesar do art. $182, \S 4^{\circ}$, da CF, bem como o art. $8^{\circ}$, caput, da Lei $10.257 / 01$, servirem-se do vocábulo "proprietário", nada impede que a posse de boa fé, como exteriorização do domínio, seja alcançada pela medida em tela.

Do mesmo modo, os terrenos pertencentes às pessoas políticas e administrativas não se encontram excluídos da desapropriação para reforma urbana. A uma, porque ao Poder Público, em face de subordinar-se aos ditames da ordem jurídica que elabora, incumbe, com maior razão, legar aos seus bens uma função, quer projetando-o à fruição de toda a coletividade (bens públicos de uso comum do povo), quer afetando-o a determinado serviço público (bem de uso especial), quer, no tocante

9 José Bonifácio Borges de Andrade (Aspectos constitucionais da desapropriação para fins de reforma agrária. Revista da Procuradoria-Geral da República, Brasília, n. 4, p. 114), Rubens Pestana de Andrade (Desapropriação de imóveis rurais e urbanos por necessidade pública, utilidade pública, interesse social e para fins de reforma agrária. Revista dos Tribunais, n. 501, p. 234, jul. 1977) e Flávio Sant'Anna Xavier (Desaproprialidade por interesse social, pelos Estados e Municípios, de imóvel rural para fins de reforma agrária. Revista de Direito Administrativo, Rio de Janeiro, n. 225, pp. 107-108, jul./set. 2001).

10 Cf. STF, Pleno, mv, MS 22.193, rel. Min. Maurício Corrêa, DJU de 29-11-96, p. 47.160; STJ, $2^{2}$ T., ac. un., re. Min. Eliana Calmon, DJU de 13-12-99. 
ao dominiais, permitindo a sua utilização específica por particulares, ou mesmo a alienação do seu domínio útil, a fim de que aqueles os empreguem em um uso lícito. Em segundo lugar, é sabido não existir óbice à expropriação dos bens públicos, quando estes não estejam afetados a uma finalidade pública, não se cogitando nem mesmo da observância da gradação prevista no art. $2^{\circ}, \S 2^{\circ}$, do Decreto-lei $3.365 / 41^{11}$.

\section{Pressupostos}

De logo, mister admoestar que o art. $182, \S 4^{\circ}$, da CF, qualifica-se, como inelutavelmente decorre do seu texto, ao reportar-se à interpositio legislatoris, concretizável mediante a edição de leis federal e municipal, como norma de eficácia limitada.

Assim, os primeiros pressupostos para que a medida pudesse lograr operatividade se centram na edição de lei federal, delimitando a maneira como deverá ser exigido do proprietário do solo urbano não edificado, subutilizado, ou não utilizado, a promoção do seu adequado aproveitamento, cujo advento ocorreu com a Lei $10.257 / 01^{12}$, e lei municipal específica, responsável por definir a área sobre a qual tal providência deverá incidir.

O não aproveitamento do imóvel urbano implicará, inicialmente, na imposição ao proprietário ou possuidor da obrigação de parcelamento, edificação ou utilização compulsórias. Assim não laborando nos prazos mencionados no art. $5^{\circ}, \S 4^{\circ}$, da Lei 10.257/01, lançará mão o Poder Público municipal da aplicação do imposto sobre a propriedade predial e territorial urbana (IPTU) progressivo no tempo, o que se dá com a majoração de sua alíquota durante cinco anos consecutivos.

11 Cf. STF, RE 85.550-SP, rel. Min. Moreira Alves, RTJ 87/548; TFR, 6 ${ }^{\mathrm{a}}$ T., ac. un., AC 40.526 , rel. Min. Carlos Mário Velloso, RDA 173/132. Idem Celso Antônio Bandeira de Mello (Desapropriação de bem público. Revista de Direito Público, São Paulo, n. 29, p. 47, jan./mar. 1974). Assim também acontece no estrangeiro. Na Itália, por exemplo. como nos diz Pietro Virga (Diritto Amministrativo - I principi. 4. ed. Milão: Giuffrè editore, 1995. p. 484), os bens do patrimônio público disponível dos entes públicos podem ser objeto de expropriação.

12 Vitor Rolf Laubé (Desapropriação Urbanística. Revista de Informação Legislativa, Brasília, ano 29 , n. 114, p. 227, abr./jun. 1992) defendeu que, mesmo ausente a lei federal reclamada pelo art. $182, \S 4^{\circ}$, da $\mathrm{CF}$, poder-se-ia, num recurso à interpretação sistemática, suprir-se tal omissão mediante o exercício, pelo Município, da competência suplementar inserta no art. 30, II, do mesmo diploma. Essa foi a posição também exposta por Carlos Ary Sundfeld (Desapropriação. São Paulo: Revista dos Tribunais, 1990. p. 37). Com o merecido respeito que tributamos a tais opiniões, somos de que o art. 30, II, da Constituição, somente permite a utilização da legislação municipal, como fonte supletiva das legislações federal e estadual, naquilo em que for possível a atividade do Município suprir. Não abrange a hipótese, como a analisada, onde o Constituinte, às expressas, fez referência à lei federal, por ser apanágio desta uniformizar os padrōes fundamentais a gizar a política urbana em nossa federação. Assim, mais aconselhável o entendimento de Celso Ribeiro Bastos \& Ives Gandra da Silva Martins (Comentários à Constituição do Brasil. São Paulo: Saraiva, 1990. v. 7 , p. 223), ao indicar que, enquanto não adviesse a mencionada lei federal, o art. $182, \S 4^{\circ}$, da CF, seria norma inaplicável. 
Permanecendo inerte o proprietário, ao depois do transcurso do respectivo lustro, em dar cumprimento ao encargo de parcelamento, edificação, ou utilização, o Município lançará mão da desapropriação prevista no art. $182, \S 4^{\circ}$, III, da CF, editando o titular do Poder Executivo municipal, mediante decreto, a competente declaração de interesse social ${ }^{13}$.

Não obsta a desapropriação para reforma urbana a ausência de norma a definir o seu processo judicial, na hipótese de discordância do proprietário com o valor da oferta. À míngua de diploma específico, deverá ser aplicado o regramento do Decreto-lei 3.365/41, na condição de Lei Geral das Desapropriações.

\section{Indenização}

A compensação financeira devida ao proprietário apresenta, na modalidade aqui examinada, algumas peculiaridades que a distinguem das verificadas nos demais tipos de expropriação.

Inicialmente, impende asseverar que, contrariamente à desapropriação ordinária (art. $5^{\circ}, \mathrm{XXIV}, \mathrm{CF}$ ), e à desapropriação-sanção para reforma agrária (art. 184, caput, $\mathrm{CF}$ ), a Lei Maior, no art. $182, \S 4^{\circ}$, III, somente fez referência ao valor real da indenização, em nada precisando se o pagamento da indenização deverá ou não anteceder a perda da propriedade.

Isso equivale a dizer que, na espécie em comento, não há garantia de que a indenização seja prévia. Poderá, portanto, o legislador estabelecer que a mutação dominial no registro imobiliário se dê antes de quitado o valor do ressarcimento devido ao proprietário ou possuidor.

13 Escrevendo antes da Lei 10.257/01, Carlos Ary Sundfeld (Desapropriação. São Paulo: Revista dos Tribunais, 1990. pp. 37-38) sustentava que o vocábulo "sucessivamente" não obriga ao Município que primeiro exija o parcelamento ou a edificação compulsórios para, fracassados estes, passar à cobrança do IPTU de forma progressiva e, apenas à derradeira, efetuar a desapropriação. Adentrando no terreno exemplificativo, diz que pensar contrário poderá conduzir a absurdos, como quando, com relação a edifício desabitado, e que por isto também deixa de cumprir a sua função social, veja-se o Município na injunção de impor a providência de edificação compulsória. A Lei $10.257 / 01$, por seu tumo, determinou que as medidas elencadas no art. $182, \S 4^{\circ}$, I a III, da CF, sejam tomadas de modo sucessivo. Para pôr cobro a possível contenda e, ao mesmo tempo, evitar situações disparatadas, conforme a advertência do mestre bandeirante, faz-se mister a adoção de inteligência que libere o Poder Público de uma das fases antecedentes quando tal for inviável. Desse modo, no caso de edifício não habitado poderia, de pronto, o Município proceder à exigibilidade do IPTU com alíquotas dotadas de progressividade para, posteriormente, se ainda for necessário, desapropriar. Já o direito espanhol, ao cuidar da expropriação pelo não cumprimento da função social da propriedade, a exemplo da desapropriação para fins de composição urbana da legislação portuguesa, preconiza iter mais simplificado. Assim, o art. 72 da Ley de 16 de dezembro de 1954 enumera os seguintes antecedentes: a) declaração, originária de lei ou decreto do Conselho de Ministros, de que um certo bem, ou uma categoria de bens, deve sofrer determinadas transformaçōes, ou ser utilizado de maneira específica; b) a necessidade de a lei ou decreto conter a cominação de expropriação, no caso de seu descumprimento; c) fixação de prazo para a realização da função social e que, após o seu vencimento, aquela não resulte, total ou parcialmente, adimplida. 
Essa orientação goza de prestígio na doutrina ${ }^{14}$, sem contar que outrora esse pensar fora sufragado pela jurisprudência quanto à desapropriação por interesse social para fins de reforma agrária. Sob a consideração de que o art. 161 da Constituição de 1967 , com a redação ofertada pela EC 01/69, somente se reportava à indenização justa, o Supremo Tribunal Federal entendeu constitucional o art. $3^{\circ}$, II e III, do Decreto-lei 554/69, a cuja aplicação estava subordinado o seu famigerado art. $7^{\circ}$, que determinava, initio litis, a transcrição do imóvel em favor do exproprian$\mathrm{te}^{15}$.

Havendo, no entanto, omissão legal nesse sentido, forçosa a incidência do art. 29 do Decreto-lei 3.365/41, na condição de norma genérica a disciplinar a matéria, estabelecendo que a imissão definitiva na posse, juntamente com a transcrição no registro imobiliário, somente ocorrerá com o pagamento da indenização, ou consignação de seu preço.

Ao contrário de respeitáveis opiniões, não restou afastada a necessidade de compensação justa. Diferentemente, Carlos Ary Sundfeld ${ }^{16}$ indica que a expressão "valor real", insculpida no art. $182, \S 4^{\circ}$, III, da CF, não se confunde com valor justo, visando apenas assegurar que o valor da indenização, expresso em títulos, não sofra os efeitos da desvalorização da moeda entre a sua consignação e o seu efetivo resgate.

Ouso discordar. A dicção constitucional não dá azo a dúvidas. Reporta-se a "valor real da indenização", mostrando que a coisa não poderá ser expropriada por preço inferior ao que ostenta. A expressão "valor real", em sede expropriatória, não tem o seu significado reduzido à necessidade de incidência de correção monetária. Absolutamente. Como bem nos mostrou o Min. Moreira Alves, ao conduzir votação no RE 99.849-PE, “indenização justa é, sem dúvida alguma, a compensação em dinheiro que reponha, o mais exatamente possível, no patrimônio do desapropriado, o valor real da coisa daí retirada" ${ }^{17}$.

Em harmonia com o entendimento de que a expressão "valor real" não deve ser aqui concebida como substitutivo de atualização monetária, tem-se que o legis-

14 Cf. Lúcia Vale Figueiredo (Curso de Direito Administrativo. São Paulo: Malheiros, 1994. p. 217). Ensina, a propósito, Carlos Ary Sundfeld que "o pagamento (é dizer, a entrega dos títulos da dívida pública) pode, nos termos do que vier a prever a lei, ser feito após a aquisição da propriedade pelo Município" (Desapropriação. São Paulo: Revista dos Tribunais, 1990. p. 40). No mesmo sentido, Clóvis Beznos (Desapropriação. In: MELLO, Celso Antônio Bandeira de. Direito administrativo na Constituição de 1988. São Paulo: RT, 1991. p. 115).

15 Pleno, mv, RE 99.849-PE, rel. Min. Moreira Alves, RTJ 108/793. Desse julgamento bom destacar o voto do Min. José Néri da Silveira, ao invocar anterior pronunciamento no Tribunal Federal de Recursos (AI 38.537 - MG), onde se expressou: "Desde o Ato Institucional $n^{\circ}$ 9, de 1969, portanto, retirou-se do texto constitucional, no que concerne à desapropriação por interesse social, para fins de reforma agrária, a expressão 'prévia' indenização, mantendo-se, porém, a fórmula 'justa indenização' acrescida da cláusula 'fixada segundo os critérios que a lei estabelecer'. (RTJ 108/808).

16 Loc. cit., p. 40. Idem Lúcia Vale Figueiredo (Curso de Direito Administrativo. São Paulo: Malheiros, 1994. p. 217) e Celso Ribeiro Bastos \& Ives Gandra da Silva Martins (Comentários à Constituição do Brasil. São Paulo: Saraiva, 1990. v. 7, p. 223).

17 A parte em negrito não consta do original (RTJ 108/801). 
lador, no pórtico do $\S 2^{\circ}$ do art. $8^{\circ}$ da Lei $10.257 / 01$, dela se utiliza como se estivesse se referindo ao montante da retribuição a ser paga pelo expropriante.

E não poderia ser diferente, já que a atividade legislativa há de seguir os padrões gerais constantes do arcabouço constitucional, de onde não se pode sonegar o princípio da justiça, consagrado como objetivo fundamental da República Federativa do Brasil no art. $3^{\circ}, I$, da CF. Daí decorre, portanto, que, na ponderação das vertentes exegéticas a disputar a primazia do significado do que se deva depreender por "valor real", o primado tocará àquela que se incline pela justeza da indenização, até porque, em caso de suposta lacuna no texto do art. $182, \S 4^{\circ}$, III, da CF, a franquia da justa reparação ao expropriado há de ser inferida como direito fundamental implícito (art. $5^{\circ}, \S 2^{\circ}, \mathrm{CF}$ ), resultante do regime e dos princípios inerentes ao Estado Democrático de Direito.

A aceitação do ponto de vista de que, na desapropriação em comento, o ressarcimento há de ser justo, implica incompatibilidade vertical do art. $8^{\circ}, \S 2^{\circ}$, I, da Lei $10.257 / 01$, quando diz que o valor real da indenização refletirá a importância da base de cálculo do IPTU.

Não nego a possibilidade de o legislador estabelecer os parâmetros mediante os quais possa o aplicador do direito aportar na fixação da justa indenização. No entanto, há de atuar em atenção a critérios de razoabilidade, desviando-se de traçar limites absolutos que impeçam o proprietário de questionar a busca do valor devido.

Não teria visto maiores problemas se perfilhado o critério do valor de mercado, porquanto este condiz com a perda a ser suportada pelo proprietário e, portanto, hábil para o fim a que busca a garantia da justa indenização. Contrariamente se tem quando eleito, como limite insuperável da compensação, um valor abstrato, muitas vezes distanciado, na prática, da avaliação atual do imóvel, como se tem com a escolha do valor venal do imóvel, constante nos cadastros municipais para fins de cobrança do IPTU, na maioria das vezes desatualizado e, atém mesmo, irreal.

O Supremo Tribunal Federal, em caso similar, retratado pelo citado RE 99.849 - PE, já manifestou seu desapreço com tal opção legislativa, ao reputar inconstitucional o art. 11 do Decreto-lei 554/69 que, para fins de desapropriação por interesse, para fins de reforma agrária, dispunha que, a revisão do valor da indenização, deveria ser respeitado, em qualquer caso, como limite máximo, a estimativa declarada pelo proprietário, para efeito de cálculo do Imposto Territorial Rural ${ }^{18}$.

Assim, muito embora seja de uma maior praticidade ao Município, ao agitar o procedimento expropriatório, estabelecer a sua oferta com observância da importância com base na qual é calculado o IPTU, nada estará a impedir que o proprietário, citado, conteste tal quantum como representativo do valor real do bem.

18 Interessante, sem sombra de dúvida, a leitura do voto discordante do Min. Francisco Rezek, ao não vislumbrar abusiva a conduta do legislador ordinário ao escolher como parâmetro do valor da indenização o declarado pelo proprietário para fins de lançamento do ITR (RTJ 108/802). 
A Lei $10.257 / 01$, no seu art. $8^{\circ}, \S 2^{\circ}$, II, exclui a possibilidade de pleito, pelo expropriado, de lucros cessantes ou expectativas de ganho, o que nem precisava ser enfática, haja vista que a medida tem como alvo imóvel não adequadamente aproveitado.

O mesmo dispositivo, em sua parte final, exclui a condenação do expropriante no pagamento de juros compensatórios. Pergunta-se: poderá, em face disso, vir a sofrer censura do Judiciário? Sou pela negativa.

O primeiro argumento se origina de meditação de Cretella Júnior ${ }^{19}$, ao chamar a atenção para o fato de se distinguirem imóveis que possuem valor, mas também produzem renda, dos que apenas podem ser suscetíveis de avaliação em dinheiro. Sendo assim, somente quanto aos primeiros é que caberia falar-se em juros compensatórios. Da lição do mestre, forçosa seria a conclusão de que, na desapropriação para reforma urbana, incidente sobre imóveis que relegam a sua função social, estaria excluída a possibilidade de serem devidos juros compensatórios.

É certo que esse pensar, embora recentemente tenha sensibilizado a jurisprudência ${ }^{20}$, ao provocar uma reabertura na discussão do tema, fora rechaçado pelo Supremo Tribunal Federal na ADInMC 2.332-DF ${ }^{21}$, podendo-se, com isso afirmar ser incompatível a exclusão dos juros compensatórios. Ledo engano. Outro raciocínio merece ser exposto nas linhas seguintes.

No referido julgamento, resultou inconstitucional o art. $15-\mathrm{A}, \S \S 1^{\circ}$ e $2^{\circ}$, do Decreto-lei 3.365/41, introduzido pela MP 2.027-43/00, que reservara aos juros compensatórios o papel de reparar a perda de renda efetivamente sofrida pelo proprietário com a medida estatal. Para esse fim, fê-lo o Pretório Excelso sob o argumento de que a rubrica em questão serve, ao invés de lucros cessantes, para remunerar o capital que o particular deixou de receber desde a perda da posse do bem, por o expropriante não haver diligenciado, de logo, o pagamento da indenização realmente devida, tanto que a base de cálculo para a incidência da rubrica corresponde à diferença entre o valor fixado na sentença e $80 \%$ do depósito prévio, cuja disponibilidade ao expropriado não está obstada. Assim, considerando-se que, na expropriação para reforma urbana, a despeito de sua indenização encontrar-se jungida ao imperativo de justeza, não se impõe seja prévia, razão pela qual o seu não pagamento integral, quando da imissão na posse, não enseja compensação em prol do proprietário. A infringência à justa indenização, conforme se pode perceber da notícia do julgamento do Supremo Tribunal Federal, está ligada à circunstância de, antes da

19 Desistência da desapropriação, RT 617/10-11.

20 Cf. o decidido nos arestos, a saber: REsp 228.481- MA (STJ, 1* T., ac. un., rel. Min. José Delgado, DJU de 20-03-00, p. 00046), REsp 108.896 - SP (STJ, 1 T., mv, rel. Min. Milton Luiz Pereira, DJU de 30-11-98, p. 00049), AgRg no REsp 296.431-SP (STJ, 2 Turma, ac. un., rel . Min. Eliana Calmon, julgado em 24.04.2001, Informativo STJ $\mathrm{n}^{\circ}$ 93, de 23 a 27 de abril de 2001) e AC 205.767-CE (TRF - 5* Reg., $2^{\mathbf{a}}$ T., mv, rel. Des. Fed. Edilson Nobre (convocado), DJU - II de 09.11.2001, p. 666/732).

21 Pleno, mv, rel. Min. Moreira Alves, Informativo - STF no. 240. 
imissão na posse, não haver sido respeitado o postulado da prévia indenização, de cujo cumprimento na espécime não se cogita.

De concluir-se, por isso, que a exclusão dos juros compensatórios, procedida pelo legislador, não colide com os ditames constitucionais regentes da matéria.

São devidos juros de mora, à alíquota ânua de seis por cento, contados desde o trânsito em julgado ${ }^{22}$, incidente sobre o resultado da subtração do valor da indenização e o da oferta, ambos corrigidos. Também a diferença encontrada entre o valor devido e a oferta sofrerá correção, a partir do laudo pericial ${ }^{23}$.

Outra especificidade da desapropriação em foco está em que o montante da indenização é solvido, na sua inteireza, em títulos da dívida pública, cuja emissão, já existente quando da instauração do procedimento, deverá lograr prévia aprovação do Senado Federal. Tais títulos, resgatáveis no intervalo de até um decênio, em prestações anuais, iguais e sucessivas, além de portarem cláusula de correção monetária, pena de diminuição de seu valor com o desgaste da moeda, sofrem o cômputo de juros legais de seis por cento ao ano até o seu efetivo resgate. Interditou o art. $8^{\circ}, \S 3^{\circ}$, da Lei $10.257 / 01$, que os títulos em causa ostentem poder liberatório para a quitação de tributos.

Cuidando-se de pagamento a ser efetuado em títulos, poderia haver o legislador adotado regra semelhante à constante do art. 15 da Lei Complementar 76/93, dispensando a expedição de precatório, providência em concerto com o art. $100 \mathrm{da} C F$, o qual, nos termos do deliberado pelo Supremo Tribunal Federal no RE 247.866-1$\mathrm{CE}^{24}$, refere-se unicamente às quantias devidas pela fazenda pública em dinheiro.

Contestado o preço indicado pelo expropriante, a sentença, caso conclua pela sua elevação, condenará aquele ao pagamento, em prol do expropriado, de honorários advocatícios, calculados sobre a diferença entre a indenização e a oferta, ambas corrigidas $^{25}$. Nessas hipóteses, arcará ainda o expropriante com as despesas que teve o expropriado para contratar assistente técnico.

\section{Súmula 70-STJ.}

23 Súmulas 561-STF e 67-STJ.

24 A ementa do julgado está assim redigida: "ADMINISTRATIVO. DESAPROPRIAÇÃO. INDENIZAÇĀO DE BENFEITORIAS. ALEGADA OFENSA DOS ARTS. 14, 15 E 16 DA LEI COMPLEMENTAR N ${ }^{\circ} 76 / 93$ AO ART. 100 DA CONSTITUIÇÃO FEDERAL. O art. 14 da Lei Complementar $n^{\circ} 76 / 93$, ao dispor que o valor da indenização estabelecido por sentença em processo de desapropriação para fins de reforma agrária deverá ser depositado pelo expropriante em dinheiro, para as benfeitorias úteis e necessárias, inclusive culturas e pastagens artificiais, contraria o sistema de pagamento das condenações judiciais, pela Fazenda Pública, determinado pela Constituição Federal no art. 100 e parágrafos. Os arts. 15 e 16 da referida lei complementar, por sua vez, referem-se, exclusivamente, às indenizaçōes a serem pagas em títulos da dívida agrária, posto não estar esse meio de pagamento englobado no sistema de precatórios. Recurso extraordinário conhecido e provido, para declarar a inconstitucionalidade da expressão "em dinheiro, para as benfeitorias úteis e necessárias, inclusive culturas e pastagens artificiais e", contida no art. 14 da Lei Complementar n 76/93.". (Pleno, mv, rel. Min. Ilmar Galvão, DJU de 24-11-00).

25 Súmulas 617-STF e 141-STJ. 


\section{Destinação do bem expropriado}

No que concerne ao destino do seu objeto viceja traço distintivo entre as expropriações por utilidade ou necessidade pública e por interesse social. É que, enquanto nas primeiras o bem adquirido permanece com o expropriante, a fim de ser afetado a obras e serviços públicos, nas segundas a sua vocação é para entrega a terceiros, proporcionando-se, assim, a justa distribuição da propriedade.

A medida em análise, malgrado encaixar-se no gênero de desapropriação para interesse social, traduz exceção à regra geral, havendo a possibilidade, prevista no art. $8^{\circ}, \S 4^{\circ}$, da Lei $10.257 / 01$, de o Município promover o adequado aproveitamento do imóvel no prazo máximo de um lustro, computado desde a incorporação deste em seu acervo patrimonial.

Faculta 0 art. $8^{\circ}, \S 5^{\circ}$, da Lei $10.257 / 01$, que o Município, no lugar de diretamente patrocinar o correto aproveitamento do imóvel, aliene ou conceda o seu uso a terceiros mediante procedimento de licitação. Assim ocorrendo, o beneficiário com o domínio ou posse do bem passará a ser responsável pelos encargos previstos no art. $5^{\circ}$ do mencionado diploma.

Tal obrigação deverá figurar, no ato de aquisição ou concessão, como condição resolutiva, apta a ensejar, de pleno direito, o retorno do bem ao Poder Público, que poderá deliberar por explorá-lo diretamente, ou mediante transferência de seu domínio ou posse a novo interessado. Silente o contrato, restará ao Município a via, assaz delongada, de lançar mão do IPTU progressivo para, ao final de cinco anos, se for o caso, promover nova desapropriação, o que, além de não aconselhável, é ineficiente.

Merece ainda destaque que, na reforma urbana, mesmo cuidando-se de expropriação por interesse social, outra exceção aos postulados gerais desta consiste na possibilidade de cogitar-se dos pressupostos do instituto da retrocessão, com o retorno do bem ao expropriado.

Essa assertiva aqui se impõe sem a menor margem de dúvida. Poderá ocorrer, por exemplo, que o Município, assumindo a obrigação de levar a cabo o adequado aproveitamento do bem, mantenha-se inerte em fazê-lo ao depois do transcurso do prazo de cinco anos, demarcado no art. $8^{\circ}, \S 4^{\circ}$, da Lei 10.257/01. Estará, em tese, corporificada a situação de abandono, a dar azo à retomada do bem.

No particular da transferência do imóvel a terceiro, poder-se-á, caso o Município não atue com o cuidado necessário, inerente à fiscalização do adequado aproveitamento do bem, restar caracterizado, no mundo fático, desvio de finalidade, em virtude da indevida permanência do bem com aquele. É que ter-se-á, sem causa jurídica, expropriação em benefício de interesse privado, resultado vergastado pelo Supremo Tribunal Federal ${ }^{26}$.

A peremptória negativa do direito à retrocessão, nessa hipótese, será capaz de favorecer a ocorrência de desapropriação como maneira de enriquecimento de terceiros, possíveis aliados dos governantes da entidade expropriante. Para obviar 
situações desse jaez, a Ley de 16 de dezembro 1954, no seu art. 74, comina multa ao beneficiário da expropriação, por igualmente não haver, no prazo assinado, legado ao bem sua função social.

\section{Algumas conclusões}

Ao término do exposto, dignas de serem sumariadas as seguintes conclusões:

a) a propriedade deixou de ser concebida como um instituto ilimitado, representando, inversamente, um direito jungido ao cumprimento de uma função social pelo seu titular, o que se impõe, em nossa sociedade, assinalada pela explosão demográfica nas cidades, não apenas no setor campesino, mas, com maior razão, na província urbana, a fim de satisfazer frente à aguda crise de moradia, cujo desrespeito poderá ensejar o manejo, pelo Poder Público, da desapropriação-sanção;

b) a figura expropriatória do art. $182, \S 4^{\circ}$, III, da Lei Básica, cuja competência pertence, com exclusividade aos Municípios, tem por alvo imóveis urbanos, particulares ou públicos disponíveis, sitos em área delimitada no plano diretor, não adequadamente aproveitados pelo proprietário, ou possuidor;

c) a implementação da desapropriação para fins de reforma urbana reclama, inicialmente, a edição de lei federal, disciplinando a maneira como o proprietário de imóvel urbano deve proceder ao seu devido aproveitamento, juntamente com lei municipal, a qual tocará individualizar as áreas de sua incidência; integrado o quadro legislativo, caberá ao Município, antes de lançar mão da expropriação, impor ao proprietário ou possuidor o parcelamento, ou edificação compulsórios, e o IPTU com a alíquota progressiva;

d) a despeito de não haver obrigação de ser prévia a compensação a ser paga ao expropriado, mediante a entrega de títulos da dívida pública, aquele não se encontra privado do direito a que tal pagamento se paute em critérios de justeza, tendo em vista o Constituinte haver posto em destaque que deveria ser assegurado o valor real da indenização;

e) o destino do bem expropriado caberá ao Município, ou a terceiro, mediante licitação, os quais deverão promover o seu adequado aproveitamento dentro de cinco anos, não se descartando, de forma decisiva, que o não adimplemento de tal encargo poderá, em tese, caracterizar, no mundo fático, desvio de finalidade a ser reparado mediante pleito de retrocessão. 


\section{Estudos em Homenagem ao Prof. Caio Tácito}

Org. Carlos Alberto Menezes Direito

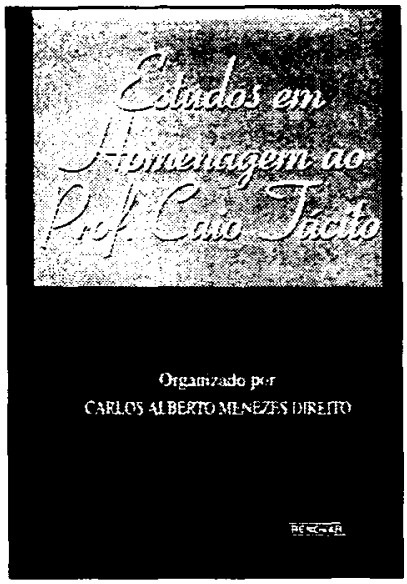

"Mestre Caio Tácito assume os oitenta anos com a bem-aventurança do respeito, da admiração, da reverência, do carinho dos seus contemporâneos". Não é sempre que um mestre dedicado ao Direito Administrativo reúne na intensidade do mesmo carinho juristas e professores de tantas áreas do direito, tal é a diversidade dos temas que compōem esta obra. $\begin{array}{ll}\text { Ref. 0153 } & \text { Encadernado } 760 \text { págs. } \\ \text { Form. 16x23 } & 1997\end{array}$

\section{Estudos Tributários}

Esta coletânea reúne estudos elaborados por tributaristas renomados. São contribuições importantes que versam tanto temas atuais, quanto questōes que de há muito ensejam controvérsias entre fisco e contribuintes. A obra se integra nos eventos que marcam a passagem do cinqüentenário da ABDF.

Ref. 0221

Form. 14x21
Brochura 1999
Org. Condorcet Rezende

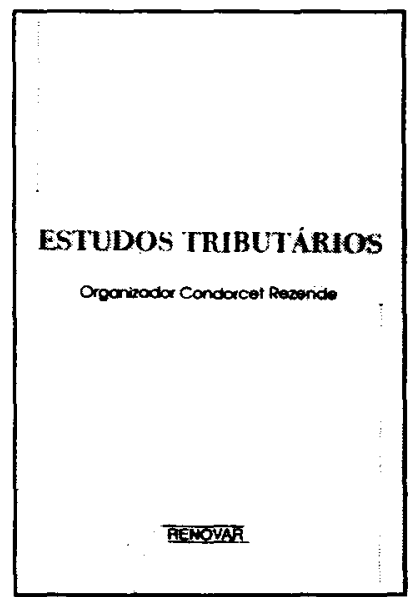

